\title{
PENGEMBANGAN MEDIA PEMBELAJARAN MELALUI PROGRAM PREZI PADA MATA PELAJARAN AL QUR'AN HADIS DI MADRASAH ALIYAH
}

\author{
Oleh: \\ Sri Andri Astuti \\ IAIN Metro Lampung \\ Email: andriasmuthia@gmail.com
}

\begin{abstract}
ABSTRAK
Penelitian ini bertujuan untuk menghasilkan media pembelajaran Al Qur'an Hadis menggunakan program prezi yang valid dan efektif. Jenis penelitian ini adalah penelitian pengembangan dengan menggunakan model pengembangan Hannafin dan Peck dengan tahapan analisis kebutuhan, desain, dan pengembangan. Penelitian ini dilaksanakan di Madrasah Aliyah Negeri 1 Metro Lampung. Subjek penelitian adalah peserta didik kelas XI IPS yang terdiri dari 2 kelas eksperimen dan 2 kelas kontrol. Teknik pengumpul data menggunakan angket untuk ahli materi, ahli bahasa, ahli media, dan peserta didik serta observasi dan tes hasil belajar. Data tersebut dianalisis dengan statistik deskriptif dan statistik inferensial, yaitu uji $\mathrm{t}$ yang sebelumnya dilakukan pengujian prasyarat berupa uji normalitas dan homogenitas. Hasil penelitian menunjukkan bahwa produk yang dikembangkan sudah sesuai dengan prosedur pengembangan Hannafin dan Peck. Produk media ini dinyatakan valid, dan efektif. Dengan demikian secara keseluruhan dapat disimpulkan bahwa media yang dikembangkan telah layak digunakan dan dikembangkan dalam proses pembelajaran Al Qur'an Hadis di Madrasah Aliyah.
\end{abstract}

Kata Kunci: Media Pembelajaran Al Qur'an Hadis, program Prezi

\section{ABSTRACT}

This study aims to produce learning media of Al Qur'an Hadis by using a valid and effective. This is a research and development by using Hannafin and 
Peck development model with stages of requirement analysis, design, and development. This research was conducted at MAN 1 Metro Lampung. The subjects were class XI IPS students consisting of 2 experimental classes and 2 control classes. Data collection techniques were questionnaires for material experts, linguists, media experts, and learners as well as observation and test of learning outcomes. The data were analyzed by descriptive statistic and inferential statistic, i.e t-test which previously conducted prerequisite test in the form of normality and homogeneity test. The results showed that the products developed were in accordance with the procedures of development of Hannafin and Peck. This media product is declared valid, and effective. Thus, it can be concluded that the media developed has been feasible to be used and developed in the learning process of Islamic Religious Education in Islamic Senior High School.

Keywords: Al Qur'an Al-Hadith Learning Media, Prezi program

\section{A. PENDAHULUAN}

Al Qur'an Hadis merupakan salah satu bagian/unsur dari mata pelajaran Pendidikan Agama Islam yang ada di madrasah yang menunjang pencapaian tujuan pendidikan nasional yaitu mengembangkan potensi peserta didik agar menjadi manusia yang beriman dan bertaqwa kepada Tuhan Yang Maha Esa. ${ }^{1 .}$ Mata pelajaran Al Qur'an Hadis bertujuan memberikan pemahaman kepada peserta didik agar dapat memahami Al-Qur'an dan Hadits sebagai sumber ajaran agama Islam dan mengamalkan isi kandungannya sebagai petunjuk dan landasan dalam kehidupan sehari-hari. Peserta didik diharapkan mampu membaca dengan fasih, menerjemahkan, menyimpulkan isi kandungan, menyalin dan menghafal ayat-ayat dan hadis-hadis terpilih serta memahami dan mengamalkannya. Untuk mencapai tujuan tersebut, maka diperlukan proses pembelajaran.

\footnotetext{
${ }^{1}$ Anonimous, Undang-Undang Sistem Pendidikan Nasional No: 20 Tahun 2003 (Jakarta: Sinar Grafika, 2003), 5.
} 
Belajar merupakan komponen pendidikan yang berkaitan dengan tujuan dan bahan acuan interaksi, baik yang bersifat eksplisit maupun implisit. Belajar diartikan sebagai suatu proses usaha yang dilakukan seseorang untuk memperoleh suatu perubahan tingkah laku yang baru secara keseluruhan sebagai hasil pengalamannya sendiri dalam interaksi dengan lingkungannya ${ }^{2}$. Pembelajaran merupakan proses interaksi antara pendidik dengan peserta didik dan sumber belajar pada suatu lingkungan belajar. Pembelajaran membutuhkan sebuah proses yang disadari dan cenderung permanen serta mengubah perilaku. Belajar membangun makna yang dilakukan melalui proses mengalami langsung, komunikasi, interaksi, dan refleksi sehingga peserta didik dapat memproduksi gagasan yang bermakna. Oleh karena itu agar komunikasi berjalan secara efektif dan efisien, maka diperlukan media pembelajaran.

Media pembelajaran merupakan segala sesuatu yang digunakan dalam kegiatan pembelajaran agar dapat merangsang pikiran, perasaan, minat, dan perhatian siswa sehingga proses interaksi komunikasi edukasi antara pendidik dan peserta didik dapat berlangsung secara efektif dan efisien. Penggunaan media pendidikan memiliki fungsi utama yaitu sebagai sarana komunikasi antara komunikator (pendidik) dan penerima (peserta didik), di mana penerima dapat memahami isi pesan yang terdapat dalam media yang digunakan pada saat pembelajaran berlangsung. ${ }^{3}$ Penggunaan media pembelajaran pada tahap orientasi pembelajaran akan sangat membantu dalam penyampaian pesan dan isi pelajaran serta memberikan makna yang lebih dari proses pembelajaran sehingga memotivasi peserta didik untuk meningkatkan proses belajarnya.

Seorang pendidik sebagai tenaga profesional yang memiliki tugas utama mendidik, mengajar, membimbing, mengarahkan, melatih, menilai, dan mengevaluasi memiliki kewajiban untuk mengikuti perkembangan ilmu

\footnotetext{
${ }^{2}$ Slameto, Belajar \& Faktor-Faktor yang Mempengaruhinya (Jakarta: Rineka Cipta, 2010), 2.

${ }_{3}^{3}$ Dewi Salma Prawiradilaga dan Eveline Siregar, Mozaik Teknologi Pendidikan (Jakarta: Kencana, 2008), 7.
} 
pengetahuan dan teknologi. Undang-Undang no 14 tahun 2005 tentang Guru dan Dosen pasal 20 menjelaskan bahwa pendidik tidak hanya memiliki kewajiban untuk memahami dan menguasai materi-materi yang diajarkan, akan tetapi juga wajib menguasai teknologi yang digunakan dalam proses pembelajaran, sehingga proses pembelajaran lebih menarik dan menyenangkan. Pemanfaatan media yang baik dan tepat, dapat merangsang pikiran, perasaan, perhatian dan minat peserta didik. $^{4}$.

Berdasarkan Undang-Undang tersebut dapat dipahami bahwa seorang pendidik tidak hanya memiliki kewajiban untuk memahami dan menguasai materi-materi yang diajarkan, akan tetapi juga wajib menguasai teknologi yang digunakan dalam proses pembelajaran, sehingga proses pembelajaran lebih menarik dan menyenangkan. Pemanfaatan media yang baik dan tepat, dapat merangsang pikiran, perasaan, perhatian dan minat peserta didik.

Perkembangan teknologi informasi yang semakin pesat di era globalisasi saat ini tentu juga berpengaruh terhadap dunia pendidikan. Pemanfaatan media pembelajaran sebagai hasil dari perkembangan teknologi pendidikan terutama media pembelajaran yang berbasis multimedia sangat diharapkan guna menunjang proses pembelajaran, terlebih pada mata pelajaran yang dianggap kurang menarik perhatian siswa.

"Sistem pembelajaran berbasis multimedia (teknologi yang melibatkan suara, gambar, dan video) dapat menyajikan materi pelajaran yang lebih menarik, tidak monoton, dan memudahkan penyampaian. Murid atau mahasiswa dapat mempelajari materi tertentu secara mandiri dengan menggunakan komputer yang dilengkapi dengan program yang berbasis multimedia. Kini telah banyak perangkat lunak yang tergolong edutainment

${ }^{4}$ Undang-Undang No. 14 Tahun 2005 tentang Guru dan Dosen dalam Martinis Yamin, Profesionalisasi Guru \& Implementasi KTSP, (Jakarta: Gaung persada, 2007), 203. 
yang merupakan perpaduan antara education (pendidikan) dan entertainment (hiburan)",5

Dengan demikian pendidik dituntut agar dapat memanfaatkan media pembelajaran sebagai hasil dari perkembangan teknologi pendidikan. Berbagai macam media pembelajaran yang dapat digunakan oleh pendidik, diantaranya dengan memanfaatkan media komputer. Banyak software yang bisa digunakan untuk membuat produk berupa aplikasi pembelajaran. Salah satu program komputer yang dapat dijadikan media pembelajaran berbasis multimedia adalah program prezi.

Program prezi sebagai salah satu program komputer dapat digunakan sebagai media pembelajaran inovatif. Prezi dapat menyampaikan ide ataupun gagasan dalam sebuah tampilan yang saling terkait antara satu slide dengan slide lainnya dengan mudah. Dengan prezi, materi pembelajaran dapat ditampilkan secara dinamis dan menarik. Slide dapat beralih atau lompat dari satu slide ke slide lainnya dengan sangat dinamis dan mudah dengan transisi yang sangat halus tanpa harus kehilangan arah. Prezi dapat melakukan zoom in atau zoom out dari sebuah slide dengan cepat dengan tampilan yang indah ${ }^{6}$. Pembelajaran dilakukan dengan menggunakan laptop yang telah ter-install software prezi, dikombinasikan dengan LCD dan perangkat audio. Dengan memanfaatkan program prezi sebagai media pembelajaran dalam mata pelajaran Al Qur'an Hadis, tentu akan menciptakan suasana belajar yang lebih komunikatif dan menarik antara pendidik dengan peserta didik.

Namun, seringkali terjadi hambatan-hambatan komunikasi dalam proses pembelajaran, yaitu verbalisme, salah tafsir, perhatian tidak terpusat, dan tidak

${ }^{5}$ Abdul Kadir dan Terra Ch. Tri Wahyuni, Pengenalan Teknologi Informasi, (Yogyakarta: Andi Offset, 2005), 24.

${ }^{6}$ I Putu Wisnu Saputra, CD Tutorial Nonlinear Presentations Series Prezi The Zooming Presentations (Jakarta: Elex Media Komputindo, 2011). 
terjadinya pemahaman ${ }^{7}$. Verbalisme terjadi karena biasanya pendidik mengajar mengajar hanya dengan penjelasan lisan (ceramah), peserta didik cenderung hanya menirukan apa yang dikatakan pendidik, sehingga peserta didik dapat menyebutkan kata tetapi tidak mengetahui artinya. Sedangkan salah tafsir ini terjadi karena biasanya pendidik hanya menjelaskan secara lisan dengan tanpa menggunakan media pembelajaran yang lain, misalnya gambar, bagan, model dan sebagainya. Hal ini menyebabkan istilah atau kata yang sama diartikan berbeda oleh peserta didik.

Adapun perhatian tidak terpusat dapat terjadi karena beberapa hal antara lain, gangguan fisik, ada hal lain yang lebih menarik mempengaruhi perhatian peserta didik, peserta didik melamun, cara mengajar pendidik membosankan, cara menyajikan bahan pelajaran tanpa variasi, kurang adanya pengawasan dan bimbingan pendidik. Hal ini menyebabkan tidak terjadinya pemahaman, artinya kurang memiliki kebermaknaan logis dan psikologis. Apa yang diamati atau dilihat, dialami secara terpisah. Tidak terjadi proses berpikir yang logis mulai dari kesadaran hingga timbulnya konsep.

Berdasarkan wawancara dengan bapak Ghufran, M.Pd.I. ${ }^{8}$ pada tanggal 3 Oktober 2017 diperoleh informasi bahwa pendidik tidak membuat perangkat pembelajaran. Pembelajaran Al Qur'an hadis selama ini lebih banyak menggunakan buku pelajaran, Lembar Kerja Siswa (LKS), papan tulis dan spidol. Pendidik sebenarnya mampu mengoperasionalkan komputer, namun karena keterbatasan waktu dan kemampuan, pendidikan jarang mengembangkan media pembelajaran yang berbasis komputer. Padahal menurutnya, untuk saat ini pembelajaran berbasis komputer sangat penting, karena sekarang era teknologi. Di samping itu, dengan menggunakan media berbasis komputer pembelajaran menjadi lebih menarik, komunikatif, dan menyenangkan serta yang lebih

7 Daryanto, Media Pembelajaran: Peranannya Sangat Penting dalam Mencapai Tujuan Pembelajaran (Yogyakarta: Gava Media, 2016), 9.

${ }^{8}$ Pendidik Mata Pelajaran Al Qur'an Hadis di Madrasah Aliyah Negeri 1 Metro. 
penting adalah mengurangi verbalisme dan mengatasi hambatan-hambatan dalam proses komunikasi dalam pembelajaran. Peserta didik juga menjadi lebih perhatian dalam belajar. Oleh karena itu diperlukan sebuah inovasi untuk mengembangkan media pembelajaran yang berbasis multimedia dengan menggunakan program prezi.

Berdasarkan uraian di atas, maka perlu dilakukan penelitian dan pengembangan guna mengatasi keterbatasan pemanfaatan media dan mempermudah peserta didik mengakses materi, dengan rumusan masalah sebagai berikut:1). bagaimana pengembangan media pembelajaran melalui program prezi pada mata pelajaran Al Qur'an Hadis di Madrasah Aliyah? 2). bagaimana kelayakan desain media pembelajaran melalui program prezi pada mata pelajaran Al Qur'an Hadis di Madrasah Aliyah berdasarkan penilaian dari ahli materi, ahli bahasa, ahli media, dan peserta didik? 3). bagaimana keefektifan media pembelajaran melalui program prezi pada mata pelajaran Al Qur'an Hadis di Madrasah Aliyah?

\section{B. KERANGKA TEORI}

1. Media Pembelajaran

Media adalah segala bentuk dan saluran yang digunakan untuk menyampaikan pesan atau informasi. ${ }^{9}$ Pengertian ini menunjukkan bahwa media merupakan alat atau sarana komunikasi yang dipergunakan oleh pemberi pesan kepada penerima pesan. Oleh karena itu media pembelajaran adalah penyalur informasi belajar atau pesan dari pendidik kepada peserta didik. ${ }^{10}$ Pendapat lain menjelaskan bahwa media pembelajaran adalah segala sesuatu yang digunakan untuk menyalurkan pesan serta dapat merangsang pikiran, perasaan, perhatian, dan kemauan si belajar sehingga dapat mendorong terjadinya proses belajar yang

\footnotetext{
${ }^{9}$ Azhar Arsyad, Media Pembelajaran (Jakarta: Rajawali Press, 2013), 3.

${ }^{10}$ Syaiful Bahri Djamarah dan Zain, Strategi Belajar Mengajar (Jakarta: Rineka Cipta, 2010), 136.
} 
disengaja, bertujuan dan terkendali ${ }^{11}$. Media pembelajaran sebagai perantara dalam proses interaksi komunikasi edukasi antara pendidik dan peserta didik yang dapat merangsang pikiran, perasaan, perhatian, minat dan perhatian peserta didik sehingga proses komunikasi tersebut dapat berlangsung secara tepat guna dan berdaya guna.

Media pembelajaran terdiri dari berbagai jenis komponen dalam lingkungan peserta didik yang dapat merangsangnya untuk belajar. Media bukan hanya berupa alat atau bahan saja, akan tetapi hal-hal lain yang memungkinkan peserta didik dapat memperoleh pengetahuan ${ }^{12}$. Dalam teknologi pendidikan, media memiliki pengertian sebagai perangkat lunak (software) dan perangkat keras (hardware). Media sebagai perangkat lunak yaitu kandungan pesan atau informasi yang terdapat dalam perangkat keras yang merupakan isi yang ingin disampaikan kepada peserta didik. Sedangkan perangkat keras sarana untuk menampilkan pesan yang terdapat dalam perangkat lunak. Media sebagai alat peraga atau alat bantu pembelajaran sering disebut dengan Audio Visual Aids (AVA). Mengingat banyaknya bentuk-bentuk media pembelajaran, maka pendidik hendaknya dapat memilih dengan cermat, sehingga dapat digunakan dengan tepat.

Dengan berkembangnya ilmu pengetahuan dan teknologi, media pembelajaran terus mengalami perkembangan dan tampil dalam berbagai jenis dan format, dengan masing-masing ciri dan kemampuannya sendiri. Secara garis besar, media pembelajaran dapat diklasifikasikan menjadi 4 (empat) kelompok besar, yaitu audio, visual, audio-visual, dan komputer. Media audio merupakan media yang hanya dapat didengar saja. Media audio mengandung pesan yang dapat merangsang pikiran dan perasaan pendengar yang dituangkan dalam lambang-lambang auditif sehingga terjadi proses belajar ${ }^{13}$. Penggunaan media audio mempunyai beberapa keuntungan, diantaranya media audio mudah

\footnotetext{
${ }^{11}$ Yusuf Hadi Miarso, Menyemai Benih Teknologi Pendidikan (Jakarta: Kencana, 2004), 458.

${ }^{12}$ Wina Sanjaya, Perencanaan dan Desain Sistem Pembelajaran (Jakarta: Kencana, 2010), 204.

${ }^{13}$ Sanjaya, Perencanaan dan Desain Sistem Pembelajaran, h. 216. Cecep Kustandi dan Bambang Sutjipto, Media Pembelajaran Manual dan Digital (Bogor: Penerbit Ghalia Indonesia, 2011), 65.
} 
digunakan dan tersedia di mana-mana. Harga media audio tidak mahal, bisa direproduksi, bisa diulang, dan portabel. Bagi peserta didik yang memiliki kemampuan membaca terbatas bisa belajar dari media audio. Media audio ideal untuk mengajarkan bahasa asing ${ }^{14}$.

Media visual merupakan media yang mengandung pesan yang dituangkan dalam lambang-lambang visual seperti tulisan, huruf-huruf, gambargambar dan simbol-simbol yang mengandung arti yang dapat merangsang pikiran dan perasaan pendengar sehingga terjadi proses belajar. Media visual terdiri dari media yang dapat diproyeksikan (projected visual) dan media yang tidak dapat diproyeksikan (non-projected visual). Media visual yang dapat diproyeksikan merupakan media yang dapat digunakan dengan bantuan proyektor, seperti film bingkai (slide), Over Head Transparancy, Opaque projector, Microfis, dan video. Setelah ada komputer, media-media proyeksi ini sudah jarang digunakan, karena komputer dapat memproyeksikan pesan lebih baik dan lebih bervariatif dengan bantuan alat proyeksi lain. Media visual yang tidak diproyeksikan disebut juga dengan media grafis. Media grafis termasuk media visual diam. Media grafis meliputi gambar/foto, diagram, bagan, poster, sketsa, grafik, media cetak dan buku.

Adapun media audio-visual adalah kombinasi dari media audio dan media visual. Media audio visual membantu pendidik menyampaikan materi kepada peserta didik agar pembelajaran lebih jelas dan konkrit. Dengan menggunakan media audio-visual maka penyajian materi kepada peserta didik akan semakin lengkap dan optimal karena melibatkan indera penglihatan dan pendengaran. Pembelajaran tidak hanya difokuskan pada alat bantu visual semata, namun sudah dilengkapi dengan suara untuk menjelaskan visualisasi materi pelajaran. Media audio-visual dalam batas-batas tertentu dapat juga menggantikan

\footnotetext{
${ }^{14}$ Sharon E Smaldino, Deborah L Lowther, dan James D Russel, Instructional Technology \& Media for Learning: Teknologi Pembelajaran dan Media untuk Belajar (Jakarta: Kencana, 2011), 7.
} 
peran dan tugas pendidik. Artinya, pendidik tidak selalu berperan sebagai penyampai materi, karena penyajian materi bisa diganti oleh media. Peran pendidik bisa beralih menjadi fasilitator. Pembelajaran seperti ini disebut dengan pola pembelajaran pendidik dan media. Beberapa media yang termasuk media audio-visual adalah program televisi, video pendidikan/instruksional, dan program slide suara.

Media komputer merupakan cara menghasilkan atau menyampaikan materi dengan menggunakan sumber-sumber berbasis mikroprosesor. Media komputer menyimpan materi atau informasi dalam bentuk digital, bukan dalam bentuk cetakan atau visual. Pemanfaatan komputer dalam pembelajaran disebut dengan Computer Assisted Instruction (CAI) yang dikembangkan dalam beberapa format, antara lain drills and practice, tutorial, simulasi, permainan, dan discovery. ${ }^{15}$ Penggunaan media komputer dalam pembelajaran meliputi multimedia presentasi (Microsoft power point, corel presentation, prezi), multimedia interaktif, dan internet. Komputer juga telah digunakan untuk mengadministrasikan tes dan pengelolaan administrasi sekolah.

Keuntungan media komputer adalah dapat mengakomodasi peserta didik yang lambat menerima pelajaran karena pembelajaran lebih bersifat individual; dapat merangsang peserta didik mengerjakan latihan dan melakukan kegiatan laboratorium atau simulasi; kendali berada di tangan peserta didik sehingga tingkat kecepatan belajar peserta didik disesuaikan dengan tingkat penguasaannya.

Kehadiran media dalam pembelajaran sangat membantu peserta didik untuk memahami suatu konsep tertentu yang sulit dijelaskan secara verbal. Media dalam proses pembelajaran secara umum memiliki manfaat sebagai berikut: 1). Memperjelas penyajian pesan agar tidak terlalu verbalistis. Media meletakkan dasar-dasar yang konkrit untuk berfikir sehingga mengurangi verbalisme; 2). Mengatasi keterbatasan ruang, waktu, dan indra. Media dapat menyajikan obyek yang terlalu besar, obyek yang kecil, gerak yang terlalu lambat atau cepat,

${ }^{15}$ Arsyad, Media Pembelajaran, .........., 33. 
kejadian atau peristiwa yang terjadi di masa lalu, obyek yang terlalu kompleks, dan konsep yang terlalu luas; 3). Penggunaan media pendidikan yang tepat dan bervariasi dapat mengatasi sikap pasif peserta didik. Pembelajaran akan lebih menarik perhatian peserta didik sehingga dapat menumbuhkan motivasi belajar; dan 4). Memberikan perangsang yang sama, mempersamakan pengalaman, dan menimbulkan persepsi yang sama. ${ }^{16}$

Dengan demikian media pembelajaran bermanfaat untuk memperjelas dan mempermudah konsep yang abstrak dan mempertinggi daya serap dan retensi belajar. Di samping itu media juga dapat memotivasi belajar dan membangkitkan kreativitas peserta didik serta belajar berpikir tingkat tinggi. Media pembelajaran dapat menimbulkan gairah belajar, memungkinkan interaksi yang lebih langsung antara peserta didik dengan lingkungan dan kenyataan serta memungkinkan peserta didik belajar sendiri-sendiri menurut kemampuan dan minatnya. Peserta didik dapat lebih banyak melakukan kegiatan belajar, tidak hanya mendengarkan penjelasan pendidik, tetapi juga aktivitas lain seperti bertanya, berpendapat, mengamati, melakukan, mendemostrasikan, memerankan, dan lain-lain.

Sebelum menentukan dan menggunakan media pembelajaran, seorang pendidik hendaknya merencanakan dan merancang media pembelajaran tersebut. Kegiatan merencanakan dan merancang media pembelajaran ini disebut dengan pengembangan media pembelajaran. Dalam proses pengembangan media pembelajaran hendaknya pendidik memperhatikan ketentuan dengan pertimbangan bahwa penggunaan media harus benar-benar berhasil guna dan berdaya guna untuk meningkatkan dan memperjelas pemahaman peserta didik. Adapun prosedur pengembangan media adalah sebagai berikut: 1). Menganalisis kebutuhan dan karakteristik peserta didik; 2). Merumuskan tujuan instruksional;

${ }^{16}$ Arief Sadiman et.al, Media Pendidikan: Pengertian, Pengembangan, dan Pemanfaatannya (Jakarta: Rajawali Press, 2012), 17. 
3). Merumuskan butir-butir materi; 4). Mengembangkan alat pengukur keberhasilan; 5). Menulis naskah media; dan 6). Mengadakan tes dan revisi ${ }^{17}$.

Dari langkah-langkah pengembangan media tersebut, selanjutnya secara rinci diuraikan pada teknik pengembangan media dengan menggunakan multimedia presentasi. Teknik pengembangan multimedia presentasi dimulai dari identifikasi program, yaitu melihat kesesuaian program yang dibuat dengan materi dan peserta didik yang meliputi latar belakang kemampuan, usia, serta jenjang pendidikan. Selain juga mengidentifikasi ketersediaan sumber pendukung seperti gambar, animasi, video, dan lain-lain. Langkah selanjutnya adalah mengumpulkan bahan pendukung sesuai dengan kebutuhan materi dan sasaran seperti video, gambar, animasi, dan suara. Setelah data terkumpul dan materi sudah dirangkum, selanjutnya proses mengerjakan program hingga selesai dan dilakukan review dari aspek bahasa, teks, tata letak, dan kebenaran konsep. Setelah revisi, program siap $\operatorname{digunakan}^{18}$.

\section{Program Prezi}

Prezi adalah sebuah perangkat lunak untuk presentasi berbasis internet $(\mathrm{SaaS}){ }^{19}$.Prezi digunakan sebagai alat untuk membuat presentasi dalam bentuk linier maupun non-linier. Presentasi linier adalah presentasi terstuktur, artinya tampilan yang satu dengan yang lainnya berurutan. Sedangkan presentasi non linier adalah presentasi yang berbentuk peta-pikiran (mind-map) sebagai contoh dari presentasi non-linier. Pada Prezi, teks, gambar, video, dan media presentasi lainnya ditempatkan di atas kanvas presentasi, dan dapat dikelompokkan dalam bingkai-bingkai yang telah disediakan. Pengguna kemudian menentukan ukuran

17 Musfiqon, Pengembangan Media \& Sumber Pembelajaran, 162. Sadiman et.al, Media Pendidikan: Pengertian, Pengembangan, dan Pemanfaatannya, 101. Rusman, Belajar dan Pembelajaran Berbasis Komputer: Mengembangkan Profesionalisme Guru Abad 21 (Bandung: Alfabeta, 2013), 171.

${ }^{18}$ Rusman, Kurniawan, dan Riyana, Pembelajaran Berbasis Teknologi Informasi dan Komunikasi: Mengembangkan Profesionalitas Guru, 302.

${ }^{19}$ https://id.wikipedia.org/wiki/Prezi diunduh tanggal 26 Juli 2016. 
relatif dan posisi antara semua objek presentasi dan dapat mengitari serta menyorot objek-objek tersebut.Untuk membuat presentasi linier, pengguna dapat membangun jalur navigasi presentasi yang telah ditentukan sebelumnya.

Prezi lebih menarik ketika dalam mode presentasi, dan lebih simpel dalam pembuatan animasi, dan pilihan tema keren dapat diunduh secara online serta dapat menggabungkan gambar, bunyi, teks, dan video dalam satu tampilan.Prezi dapat menyampaikan ide ataupun gagasan dalam sebuah tampilan yang saling terkait antara satu slide dengan slide lainnya dengan mudah. Dengan prezi, materi pembelajaran dapat ditampilkan secara dinamis dan menarik. Slide dapat beralih atau lompat dari satu slide ke slide lainnya dengan sangat dinamis dan mudah dengan transisi yang sangat halus tanpa harus kehilangan arah. Prezi dapat melakukan zoom in atau zoom out dari sebuah slide dengan cepat dengan tampilan yang indah ${ }^{20}$. Program prezi ini dapat digunakan sebagai media pembelajaran inovatif. Pembelajaran dilakukan dengan menggunakan laptop yang telah terinstall software prezi, dikombinasikan dengan LCD dan perangkat audio.

\section{METODE PENELITIAN}

1. Jenis Penelitian

Jenis penelitian ini adalah penelitian dan pengembangan. Penelitian pengembangan merupakan sebuah usaha untuk mengembangkan suatu produk yang efektif, bukan untuk menguji suatu teori. Penelitian dan pengembangan bertujuan untuk menghasilkan produk tertentu dan menguji keefektifan produk tersebut $^{21}$. Penelitian dan pengembangan ini menggunakan model penelitian dan pengembangan yang dikembangkan oleh Hannafin dan Peck. Model Hannafin dan Peck digunakan karena sesuai untuk penelitian pengembangan media pembelajaran, misalnya video pembelajaran, multimedia pembelajaran, multimedia presentasi, atau modul. Proses penelitian pengembangan Hannafin and

${ }^{20}$ Saputra, CD Tutorial Nonlinear Presentations Series Prezi The Zooming Presentations.

${ }^{21}$ Sugiyono, Metode Penelitian Kuantitatif, Kualitatif dan R\&D (Bandung: Alfabeta, 2011), 297.

Jurnal Pendidikan Agama Islam 
Peck ditempuh melalui 3 (tiga) langkah, yaitu: fase Analisis kebutuhan, desain, dan pengembangan/implementasi ${ }^{22}$. Dalam model ini, penilaian dan pengulangan dijalankan dalam setiap fase. Penilaian berbentuk formatif dan sumatif. Penilaian formatif pada model ini adalah penilaian yang dilakukan sepanjang proses pengembangan media. Sedangkan penilaian sumatif dilakukan setelah media telah selesai dikembangkan.

Kegiatan uji coba desain media pembelajaran menggunakan program prezi melalui tiga tahap, yaitu tahap uji satu per satu (one to one), tahap uji coba kelompok kecil dan tahap uji coba kelompok besar. Metode penelitian yang digunakan dalam penelitian ini adalah metode quasi eksperimen dengan desain pretest-posttest control group design. Subjek uji coba dalam penelitian ini adalah peserta didik kelas XI Madrasah Aliyah Negeri (MAN) 1 Metro.

Teknik pengumpul data dalam penelitian ini adalah angket, wawancara, dan tes hasil belajar. Angket diberikan kepada ahli media, ahli materi, dan peserta didik. Data hasil angket akan dianalisa dengan statistik deskriptif dengan skala lima yaitu dengan penskoran dari 1 sampai 5, yaitu:

Tabel 3.1

Konversi Rerata Skor menjadi Kriteria untuk Menilai Kualitas ${ }^{23}$

\begin{tabular}{|c|c|c|}
\hline Interval Skor & Kriteria & Nilai \\
\hline $\mathrm{X}>4,2$ & Sangat Baik & $\mathrm{A}$ \\
\hline $3,4<\mathrm{X} \leq 4,2$ & Baik & $\mathrm{B}$ \\
\hline $2,6<\mathrm{X} \leq 3,4$ & Cukup & $\mathrm{C}$ \\
\hline $1,8<\mathrm{X} \leq 2,6$ & Kurang & $\mathrm{D}$ \\
\hline $\mathrm{X} \leq 1,8$ & Sangat Kurang & $\mathrm{E}$ \\
\hline
\end{tabular}

${ }^{22}$ I Made Tegeh dan dkk, Model Penelitian Pengembangan (Yogyakarta: Graha Ilmu, 2014), 3.

${ }^{23}$ Sukardjo.dkk, Desain Pembelajaran Evaluasi Pembelajaran (Yogyakarta: PPs UNY, 2008), 101. 
Data hasil belajar dianalisis menggunakan uji t. Sebelum dilakukan uji t terlebih dahulu dilakukan pengujian prasyarat analisis yang terdiri dari uji normalitas dan homogenitas. Uji t digunakan untuk menguji perbedaan hasil belajar antara kelas eksperimen dengan kelas kontrol. Pengujian ini dilakukan untuk mengetahui efektivitas pengembangan media Mata pelajaran Al-Qur'an Hadis melalui program prezi. Uji t menggunakan teknik statistik independent sample t-test dengan bantuan SPSS.16

\section{HASIL PENELITIAN DAN PEMBAHASAN}

Penelitian dan pengembangan ini menggunakan model pengembangan Hannafin dan Peck secara runtut, yaitu analisis kebutuhan, desain, dan pengembangan/implementasi. Pada fase analisis kebutuhan dilakukan wawancara dengan guru Al-Qur'an Hadis Madrasah Aliyah Negeri 1 Metro mengenai proses pembelajaran selama ini, meliputi kurikulum, media, dan metode pembelajaran. Kurikulum mata pelajaran Al Qur'an Hadis di Madrasah Aliyah menggunakan kurikulum 13.

Berdasarkan wawancara dengan Ghufron, pembelajaran Al Qur'an Hadis selama ini lebih banyak menggunakan buku pelajaran, Lembar Kerja Siswa (LKS), papan tulis, dan spidol. Power point pernah digunakan, namun sangat jarang. Adapun metode yang digunakan ceramah dan drill untuk menghafal ayatayat Al-Qur'an. Pendidik sebenarnya mampu mengoperasionalkan komputer, namun karena keterbatasan waktu dan kemampuan pendidik jarang mengembangkan media pembelajaran yang berbasis komputer. Padahal menurutnya, untuk saat ini pembelajaran berbasis komputer sangat penting, karena sekarang era teknologi. Oleh karena itu diperlukan pengembangan media pembelajaran berbasis

Tahap kedua dari model Hannafin dan Peck adalah desain. Pada tahap ini, peneliti menetapkan tujuan pembelajaran, menentukan materi dan membuat media pembelajaran dengan program prezi. Berdasarkan kurikulum mata 
pelajaran Al-Qur'an Hadis di Madrasah Aliyah, dipilih materi hidup berkah dengan menghormati dan mematuhi orang tua dan guru, hidup lebih damai dengan mujahadah an-nafs, husnuzzhan, dan ukhuwah, dan hidup jadi tenang dengan menghindari pergaulan bebas dan perbuatan keji.

Setelah ditetapkan tujuan pembelajaran, maka selanjutnya menetapkan materi, metode, skenario atau kegiatan pembelajaran (RPP), dan alat evaluasi hasil belajar serta dokumen storyboard. Storyboard adalah kolom teks, audio dan visualisasi dengan keterangan mengenai content dan visualisasi yang digunakan untuk produksi sebuah program. Pada tahap ini juga mengidentifikasi video, gambar, dan teks yang berkaitan dengan materi pembelajaran. Video, gambar, dan teks tersebut diambil dari berbagai sumber, termasuk internet. Selanjutnya menentukan desain template yang digunakan dalam program prezi. Program prezi yang digunakan dalam penelitian ini adalah prezi desktop 6.16.2.0. Pada penelitian ini template yang digunakan adalah gravity, Clock, nodes, explain a topic, roadmap, dan above the clouds.

Proses pembuatan media pembelajaran mengacu kepada dokumen storyboard yang telah dibuat dengan menyesuaikan langkah-langkah pembelajaran kurikulum 2013, yaitu pendekatan saintifik, terutama pada kegiatan pengamatan. Kegiatan pembelajaran dengan pendekatan saintifik meliputi pengamatan, menanya, pengumpulan data, asosiasi, dan komunikasi. Pada kegiatan pengamatan, ditampilkan video pembelajaran dan teks-teks yang relevan dengan materi. Peserta didik mengamati video dan teks-teks yang ditampilkan serta mencatat hal-hal yang penting. Kemudian dilanjut dengan slide berikutnya yang berisi pertanyaan sebagai panduan untuk kegiatan menanya dan slide materi. Adapun untuk kegiatan eksplorasi, asosiasi, dan mengkomunikasikan tidak ditampilkan dalam slide karena kegiatan tersebut merupakan kegiatan aktif peserta didik di kelas. Pengembangan/implementasi.

Langkah selanjutnya adalah mengembangkan dan mengimplementasikan. Dalam tahap mengembangkan media pembelajaran Al-Qur'an Hadis melalui 
beberapa tahap, yaitu validasi ahli, uji satu per satu (one to one) dan uji kelompok kecil. Validasi oleh pakar materi, pakar bahasa, dan pakar media pembelajaran. Validasi materi bertujuan untuk memperoleh informasi tentang kelayakan media pembelajaran dari aspek materi. Sedangkan validasi bahasa bertujuan untuk memperoleh informasi tentang kelayakan media pembelajaran dari aspek bahasa dan validasi pembelajaran untuk memperoleh informasi kelayakan media pembelajaran dari aspek media dan meningkatkan kualitas desain media pembelajaran.

Saran dan kritik dari validator digunakan untuk meningkatkan kualitas desain media pembelajaran. Ahli materi, ahli bahasa, dan ahli media melakukan validasi dengan menggunakan kuisioner yang telah disiapkan. Ahli materi memberikan nilai rata-rata sebesar 4,58 dengan kriteria sangat baik. Ahli materi memberikan skor 5 sebanyak 7 item dan skor 4 sebanyak 5 item sehingga total nilai media pembelajaran Al-Qur'an Hadis berdasarkan aspek materi adalah 55. Sedangkan nilai rata-rata ahli bahasa sebesar 4,6 dengan kriteria sangat baik. Ahli bahasa memberikan skor 5 sebanyak 6 item dan skor 4 sebanyak 4 item sehingga total nilai media pembelajaran Al-Qur'an Hadis berdasarkan aspek bahasa adalah 46. Adapun nilai rata-rata ahli media adalah 4,67 dengan kriteria sangat baik. Ahli media memberikan skor 5 sebanyak 8 item dan skor 4 sebanyak 4 item sehingga total nilai media pembelajaran Al-Qur'an Hadis melalui program prezi berdasarkan aspek media adalah 56. Di akhir pembelajaran peserta didik diberikan angket untuk memberikan tanggapan terhadap media pembelajaran Al Qur'an Hadis menggunakan program prezi. Hasil angket peserta didik memperoleh nilai rata-rata sebesar 4,5 dengan kriteria sangat baik. Dari 15 item angket yang memperoleh 13 item berkriteria sangat baik dan 2 item memiliki kriteria baik. Berdasarkan penilaian ahli materi, ahli bahasa dan ahli media serta angket peserta didik, media pembelajaran melalui program prezi pada mata pelajaran Al Qur'an Hadis di Madrasah Aliyah merupakan media pembelajaran yang valid dan 
memiliki kriteria sangat baik. Oleh karena itu produk ini layak digunakan dan dikembangkan dalam proses pembelajaran.

Setelah dilakukan validasi desain, selanjutnya adalah revisi desain sesuai masukan ahli materi, ahli bahasa, dan ahli media sehingga produk yang dikembangkan layak untuk diimplementasikan. Pada aspek materi, revisi dengan menggunakan menambahkan contoh konkrit sesuai dengan tema dan tujuan pembelajaran. Pada aspek bahasa, revisi pada penulisan tansliterasi ArabIndonesia dan pada aspek desain (tampilan) revisi pada pemilihan gambar latar yang relevan dan kontras.

Setelah revisi desain media pembelajaran, langkah selanjutnya ujicoba satu per satu (one to one) bersama pendidik mata pelajaran Al Qur'an Hadis dan dilanjutkan dengan ujicoba kelompok kecil yang melibatkan 10 orang peserta didik dan lanjut pada implementasi. Berdasarkan masukan dari pendidik mata pelajaran Al Qur'an Hadis terjemah perkata yang semula hanya pada kata-kata sulit saja menjadi terjemahan setiap suku kata.

Tahap implementasi dilaksanakan melalui ujicoba kelompok besar yang melibatkan kelompok eksperimen dan kelompok kontrol. Kelas IPS 1 dan 3 sebagai kelas eksperimen serta IPS 2 dan IPS 4 sebagai kelas kontrol. Kelas eksperimen menggunakan media dengan program prezi dan kelas kontrol menggunakan media cetak (LKS). Eksperimen diawali dengan pretest dan diakhiri dengan posttest. Skor pretest digunakan untuk mengetahui kemampuan awal peserta didik. Untuk mengukurnya dengan cara membandingkan rata-rata hasil belajar mahasiswa pada kelas eksperimen dan kelas kontrol. Sedangkan posttest dilaksanakan untuk mengukur tingkat keefektifan produk media pembelajaran melalui program prezi.

Keefektifan media pembelajaran dapat dilihat dari pencapaian tujuan pembelajaran dan peningkatan hasil belajar peserta didik. Dalam konsep pembelajaran, efektivitas adalah keberhasilan pembelajaran yang diukur dari 
tingkat ketercapaian tujuan setelah pembelajaran selesai dilaksanakan ${ }^{24}$. Untuk menghitungnya dengan cara mencari perbedaan hasil belajar yang dicapai oleh kelas ekperimen dengan hasil belajar kelas kontrol. Sebelum uji t, dilakukan uji prasyarat normalitas dan homogenitas. Berdasarkan hasil Kolmogorov-Smirnov di atas diketahui 1,568>0,05 dan 0,797>0,05 sehingga data tiap kelompok berdistribusi normal. Dengan demikian $\mathrm{H}_{0}$ diterima dan $\mathrm{H}_{\mathrm{i}}$ ditolak, sehingga dapat disimpulkan bahwa posttest kelas eksperimen dan kelas kontrol terdistribusi normal dan dari uji homogenitas diperoleh signifikansi yang lebih besar dari nilai alpha yang ditetapkan, yaitu 5\% (0,05), yaitu 0,963 , yang berarti $\mathrm{H}_{0}$ diterima dan $\mathrm{H}_{\mathrm{i}}$ ditolak, sehingga dapat disimpulkan bahwa matriks varians hasil posttest kelas eksperimen dan kelas kontrol homogen. Dengan demikian kelas eksperimen dan kelas kontrol memiliki varians yang sama.

Setelah hasil uji prasyarat normalitas dan homogenitas terpenuhi langkah selanjutnya adalah melakukan uji t untuk melihat perbedaan nilai hasil posttest kelas eksperimen dan kelas kontrol. Berdasarkan hasil uji t kelas eksperimen dengan kelas kontrol diperoleh $t_{\text {hitung }}$ sebesar 12,88. Jika dibandingkan dengan

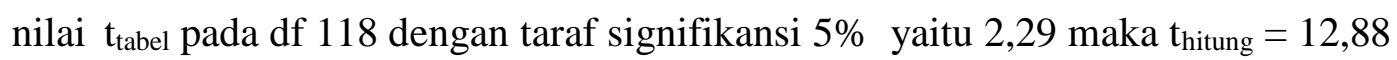
$>\mathrm{t}_{\text {tabel }}=2,29$. Diketahui juga nilai signifikansi untuk nilai $\mathrm{t}$ adalah 0,000 artinya $0,000<0,05$ yang berarti $\mathrm{H}_{0}$ ditolak dan $\mathrm{H}_{\mathrm{i}}$ diterima. Dengan demikian dapat disimpulkan bahwa terdapat perbedaan yang signifikan antara hasil posttest kelas eksperimen dan kelas kontrol. Dengan adanya perbedaan hasil belajar antara kelas eksperimen dengan kelas kontrol menunjukkan bahwa media pembelajaran Al Qur'an Hadis di Madrasah Aliyah dengan menggunakan program prezi memiliki pengaruh terhadap pencapaian hasil belajar. Dengan demikian dapat disimpulkan bahwa media pembelajaran Al Qur'an Hadis di Madrasah Aliyah menggunakan program prezi efektif untuk mencapai tujuan pembelajaran.

${ }^{24}$ Musfiqon, Pengembangan Media \& Sumber Pembelajaran (Jakarta: Prestasi Pustakaraya, 2012), 116. 
Dengan adanya perbedaan hasil belajar antara kelas eksperimen dengan kelas kontrol menunjukkan bahwa media pembelajaran Al Qur'an Hadis menggunakan program prezi memiliki pengaruh terhadap pencapaian hasil belajar. Pencapaian tujuan tersebut berupa peningkatan pengetahuan dan keterampilan serta pengembangan sikap melalui proses pembelajaran. Hal ini bisa dilihat dari nilai hasil posttest kelas eksperimen yang lebih tinggi dibanding dengan hasil posttest kelas kontrol. Dengan demikian media pembelajaran Al Qur'an Hadis di Madrasah Aliyah menggunakan program prezi efektif untuk mencapai hasil belajar.

Efektivitas pembelajaran ini diukur dari tingkat ketercapaian tujuan setelah pembelajaran selesai dilaksanakan. Hasil belajar menjadi tolok ukur efektivitas pembelajaran karena pembelajaran merupakan suatu konsep dari dua dimensi kegiatan, yaitu belajar dan mengajar yang harus direncanakan dan diaktualisasikan serta diarahkan pada pencapaian tujuan pembelajaran berupa penguasaan sejumlah kompetensi dan indikatornya ${ }^{25}$.

Media pembelajaran efektif untuk mencapai tujuan pembelajaran karena media pembelajaran bermanfaat sebagai alat komunikasi guna mengefektifkan proses pembelajaran dan merupakan alat untuk mencapai tujuan pembelajaran ${ }^{26}$. Dengan adanya media pembelajaran, proses pembelajaran yang merupakan proses komunikasi dapat mengantarkan pesan-pesan yang mengandung tujuan instruksional (tujuan pembelajaran) sehingga proses pembelajaran berjalan efektif dan efisien serta dapat meningkatkan kualitas pembelajaran. Melalui media pembelajaran, hambatan-hambatan komunikasi dalam proses pembelajaran, yaitu verbalisme, salah tafsir, perhatian tidak terpusat, dan tidak terjadinya pemahaman dapat diatasi ${ }^{27}$. Dengan adanya media, peserta didik tidak hanya menggunakan indera pendengaran, tetapi juga indra penglihatan dan tidak memungkinkan pula

\footnotetext{
25 Ibid.

${ }^{26}$ Oemar Hamalik, Kurikulum dan Pembelajaran (Jakarta: Bumi Aksara, 2011), 18.

27 Daryanto, Media Pembelajaran: Peranannya Sangat Penting dalam Mencapai Tujuan Pembelajaran (Yogyakarta: Gava Media, 2016), 9.
} 
struktur tubuh yang lain. Media dapat membuat sesuatu yang abstrak menjadi konkrit, sehingga materi pembelajaran lebih mudah diterima dan dipahami.

\section{E. KESIMPULAN}

Dari keseluruhan proses penelitian dan pengembangan media pembelajaran melalui program prezi pada mata pelajaran Al Qur'an Hadis di Madrasah Aliyah menghasilkan kesimpulan sebagai berikut:

1. pengembangan media pembelajaran melalui program prezi pada mata pelajaran Al Qur'an Hadis di Madrasah Aliyah telah dengan mengikuti prosedur penelitian dan pengembangan secara runtut.

2. media pembelajaran melalui program prezi pada mata pelajaran Al Qur'an Hadis di Madrasah Aliyah merupakan media pembelajaran yang valid

3. media pembelajaran melalui program prezi pada mata pelajaran Al Qur'an Hadis di Madrasah Aliyah efektif untuk mencapai tujuan pembelajaran.

\section{DAFTAR PUSTAKA}

Abdul Kadir dan Terra Ch. Tri Wahyuni, Pengenalan Teknologi Informasi, Yogyakarta: Andi Offset, 2005

Anonimous, Undang-Undang Sistem Pendidikan Nasional No: 20 Tahun 2003, Jakarta: Sinar Grafika, 2003

Arief Sadiman et.al, Media Pendidikan: Pengertian, Pengembangan, dan Pemanfaatannya, Jakarta: Rajawali Press, 2012

Asnawir dan Usman, Media Pembelajaran

Azhar Arsyad, Media Pembelajaran, Jakarta: Rajawali Press, 2013

Cecep Kustandi dan Bambang Sutjipto, Media Pembelajaran Manual dan Digital, Bogor: Penerbit Ghalia Indonesia, 2011

Daryanto, Media Pembelajaran: Peranannya Sangat Penting dalam Mencapai Tujuan Pembelajaran, Yogyakarta: Gava Media, 2016 
Dewi Salma Prawiradilaga dan Eveline Siregar, Mozaik Teknologi Pendidikan, Jakarta: Kencana, 2008 https://id.wikipedia.org/wiki/Prezi diunduh tanggal 26 Juli 2016

I Made Tegeh dan dkk, Model Penelitian Pengembangan, Yogyakarta: Graha Ilmu, 2014

I Putu Wisnu Saputra, CD Tutorial Nonlinear Presentations Series Prezi The Zooming Presentations, Jakarta: Elex Media Komputindo, 2011

Musfiqon, Pengembangan Media \& Sumber Pembelajaran, Jakarta: Prestasi Pustakaraya, 2012

Oemar Hamalik, Kurikulum dan Pembelajaran, Jakarta: Bumi Aksara, 2011

Rusman, Belajar dan Pembelajaran Berbasis Komputer: Mengembangkan Profesionalisme Guru Abad 21 , Bandung: Alfabeta, 2013

Rusman, Kurniawan, dan Riyana, Pembelajaran Berbasis Teknologi Informasi dan Komunikasi: Mengembangkan Profesionalitas Guru

Sadiman et.al, Media Pendidikan: Pengertian, Pengembangan, dan Pemanfaatannya

Saputra, CD Tutorial Nonlinear Presentations Series Prezi The Zooming Presentations.

Sharon E Smaldino, Deborah L Lowther, dan James D Russel, Instructional Technology \& Media for Learning: Teknologi Pembelajaran dan Media untuk Belajar, Jakarta: Kencana, 2011

Slameto, Belajar \& Faktor-Faktor yang Mempengaruhinya, Jakarta: Rineka Cipta, 2010

Sugiyono, Metode Penelitian Kuantitatif, Kualitatif dan $R \& D$, Bandung: Alfabeta, 2011

Sukardjo.dkk, Desain Pembelajaran Evaluasi Pembelajaran, Yogyakarta: PPs UNY, 2008

Syaiful Bahri Djamarah dan Zain, Strategi Belajar Mengajar, Jakarta: Rineka Cipta, 2010 
Undang-Undang No. 14 Tahun 2005 tentang Guru dan Dosen dalam Martinis Yamin, Profesionalisasi Guru \& Implementasi KTSP, Jakarta: Gaung persada, 2007

Wina Sanjaya, Perencanaan dan Desain Sistem Pembelajaran, Jakarta: Kencana, 2010

Yusuf Hadi Miarso, Menyemai Benih Teknologi Pendidikan, Jakarta: Kencana, 2004 